University of Nebraska - Lincoln

DigitalCommons@University of Nebraska - Lincoln

\title{
Geophysical investigations of geology and structure at the Martis Creek Dam, Truckee, California
}

Paul A. Bedrosian

U.S. Geological Survey, pbedrosian@usgs.gov

Bethany L. Burton

U.S. Geological Survey, blburton@usgs.gov

Michael H. Powers

U.S. Geological Survey

Burke J. Minsley

U.S. Geological Survey, bminsley@usgs.gov

Jeffrey D. Phillips

U.S. Geological Survey, jeff@usgs.gov

See next page for additional authors

Follow this and additional works at: https://digitalcommons.unl.edu/usarmyresearch

Bedrosian, Paul A.; Burton, Bethany L.; Powers, Michael H.; Minsley, Burke J.; Phillips, Jeffrey D.; and Hunter, Lewis E., "Geophysical investigations of geology and structure at the Martis Creek Dam, Truckee, California" (2012). US Army Research. 181.

https://digitalcommons.unl.edu/usarmyresearch/181

This Article is brought to you for free and open access by the U.S. Department of Defense at DigitalCommons@University of Nebraska - Lincoln. It has been accepted for inclusion in US Army Research by an authorized administrator of DigitalCommons@University of Nebraska - Lincoln. 


\section{Authors}

Paul A. Bedrosian, Bethany L. Burton, Michael H. Powers, Burke J. Minsley, Jeffrey D. Phillips, and Lewis E. Hunter 


\title{
Geophysical investigations of geology and structure at the Martis Creek Dam, Truckee, California
}

\author{
Paul A. Bedrosian a,*, Bethany L. Burton ${ }^{\text {a }}$, Michael H. Powers ${ }^{\text {a }}$, Burke J. Minsley ${ }^{\text {a }}$, \\ Jeffrey D. Phillips ${ }^{a}$, Lewis E. Hunter ${ }^{b}$ \\ ${ }^{a}$ U.S. Geological Survey, Denver Federal Center, MS 964, Denver, CO 80212, United States \\ b U.S. Army Corps of Engineers, Sacramento, CA, United States
}

\section{A R T I C L E I N F O}

\section{Article history:}

Received 20 April 2011

Accepted 3 November 2011

Available online 12 November 2011

\section{Keywords:}

Earthen dams

Martis Creek

Truckee Basin

ERT

Magnetotellurics

Seismic methods

\begin{abstract}
A B S T R A C T
A recent evaluation of Martis Creek Dam highlighted the potential for dam failure due to either seepage or an earthquake on nearby faults. In 1972, the U.S. Army Corps of Engineers constructed this earthen dam, located within the Truckee Basin to the north of Lake Tahoe, CA for water storage and flood control. Past attempts to raise the level of the Martis Creek Reservoir to its design level have been aborted due to seepage at locations downstream, along the west dam abutment, and at the base of the spillway. In response to these concerns, the U.S. Geological Survey has undertaken a comprehensive suite of geophysical investigations aimed at understanding the interplay between geologic structure, seepage patterns, and reservoir and groundwater levels. This paper concerns the geologic structure surrounding Martis Creek Dam and emphasizes the importance of a regional-scale understanding to the interpretation of engineering-scale geophysical data. Our studies reveal a thick package of sedimentary deposits interbedded with Plio-Pleistocene volcanic flows; both the deposits and the flows are covered by glacial outwash. Magnetic field data, seismic tomography models, and seismic reflections are used to determine the distribution and chronology of the volcanic flows. Previous estimates of depth to basement (or the thickness of the interbedded deposits) was $100 \mathrm{~m}$. Magnetotelluric soundings suggest that electrically resistive bedrock may be up to $2500 \mathrm{~m}$ deep. Both the Polaris Fault, identified outside of the study area using airborne LiDAR, and the previously unnamed Martis Creek Fault, have been mapped through the dam area using ground and airborne geophysics. Finally, as determined by direct-current resistivity imaging, time-domain electromagnetic sounding, and seismic refraction, the paleotopography of the interface between the sedimentary deposits and the overlying glacial outwash plays a principal role both in controlling groundwater flow and in the distribution of the observed seepage.
\end{abstract}

Published by Elsevier B.V.

\section{Introduction}

Geophysical studies are commonly applied to assess and monitor the structural integrity of earthen dams. Internal erosion due to excess seepage, one of the most common causes of dam failure, can develop slowly over time as fine particles are progressively washed out of a dam's core. Seepage can also occur within the flanks or foundation meterial (Osazuwa and Chinedu, 2008), and under the increased hydraulic head of a reservoir can lead to erosion and failure. Electrical resistivity tomography (ERT) and self-potential (SP) methods are most commonly used to identify zones of anomalous seepage (Al-Saigh et al., 1994; Minsley et al., in press; Panthulu et al., 2001; Song et al., 2005). Additionally, the installation of permanent geophysical arrays and time-lapse measurements is gaining interest (Bolève et al., 2011; Sjödahl et al., 2008; Titov et al., 2000) as a monitoring tool. Seismic hazards represent another significant and often unknown risk to earthen

\footnotetext{
* Corresponding author. Tel.: +1303236 4834.

E-mail address: pbedrosian@usgs.gov (P.A. Bedrosian).
}

dams. This hazard may be quite widespread in tectonically active regions, as the geology and topography that makes a dam site favorable is often the result of recent or ongoing fault activity. Seismic reflection, ground-penetrating radar, magnetic field mapping, and LiDAR are all valuable tools for defining unknown faults at scales relevant to dams and engineered structures. However, an understanding of the regional and engineering-scale geology is crucial to translating geophysical results into definable hazards and eventual plans for mitigation.

The 190-kilometer long Truckee River is the sole outlet for Lake Tahoe (elevation 1890 meters); it flows northward through Reno, Nevada before emptying into Pyramid Lake, a remnant of Pleistocene Lake Lahontan (Fig. 1). Martis Creek joins the Truckee River 6 km east of the town of Truckee, California and $55 \mathrm{~km}$ upstream from Reno, Nevada. Upstream from this junction, the Martis Creek Dam was completed in 1972 by the U.S. Army Corps of Engineers (USACE) to provide flood control and future water supply for the downstream area.

The dam is a rolled, earth-fill structure placed across the stream valley with sharply rising volcanic flows on the east abutment and a broad glacial outwash deposit on the west abutment. The dam is 
$815 \mathrm{~m}$ in length at its crest with a maximum height of $34.5 \mathrm{~m}$ above the original streambed (USACE, 1972). The crest of the dam is at $1785.8 \mathrm{~m}$ elevation and a spillway to the west of the dam is at
$1779.0 \mathrm{~m}$ elevation. At gross pool (maximum reservoir elevation, $1784.3 \mathrm{~m}$ ), the expected water storage is $0.0247 \mathrm{~km}^{3}$ (20,000 acre$\mathrm{ft})$. The dam was constructed with an impervious upstream blanket,

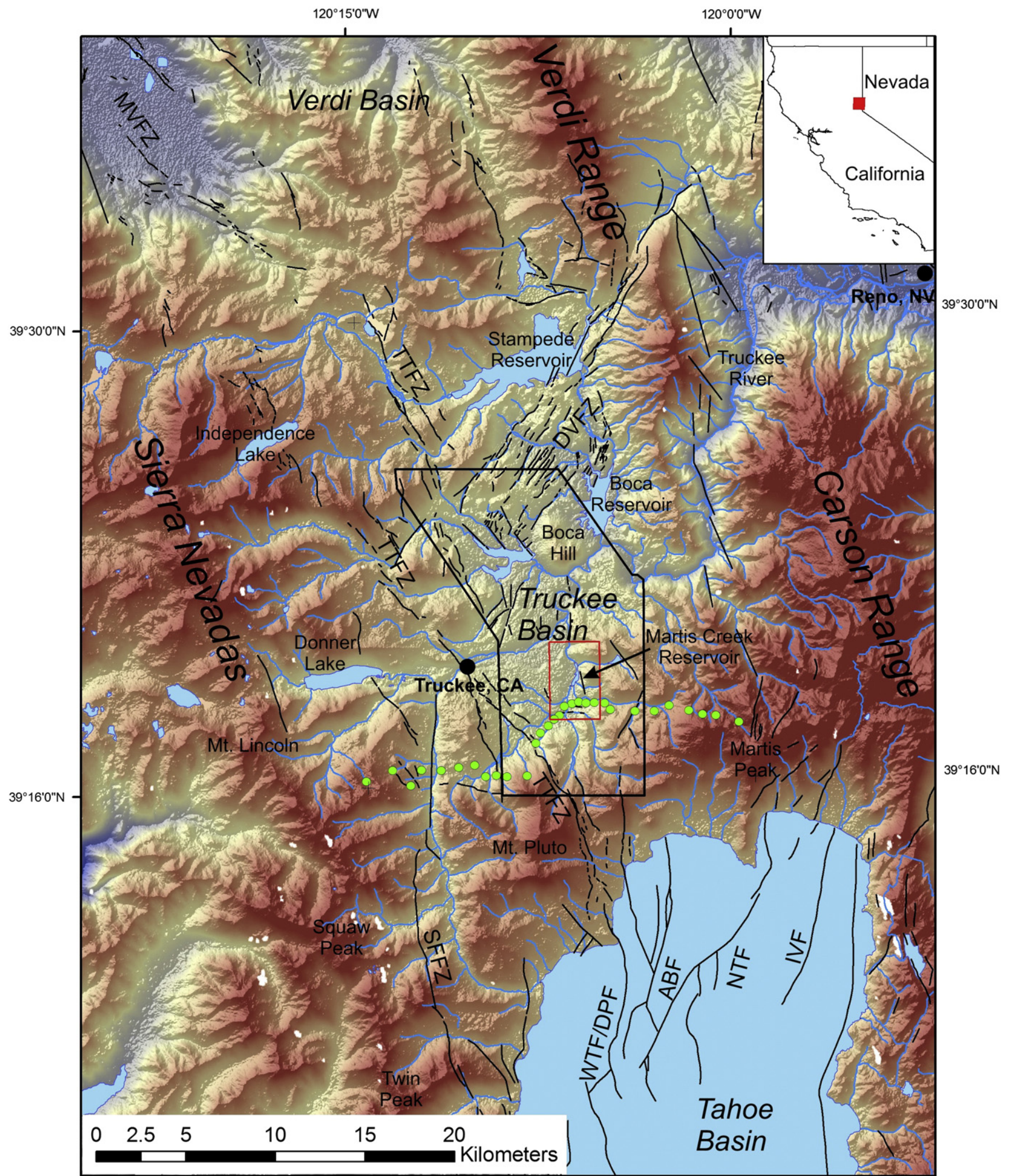

$120^{\circ} 15^{\prime} 0^{\prime \prime} \mathrm{W}$

$120^{\circ} 0^{\prime} 0^{\prime \prime W}$

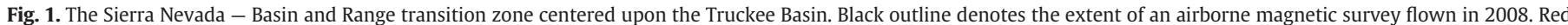

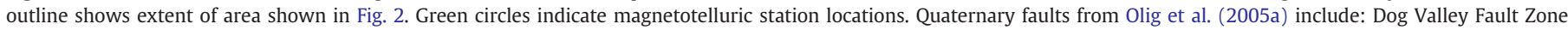

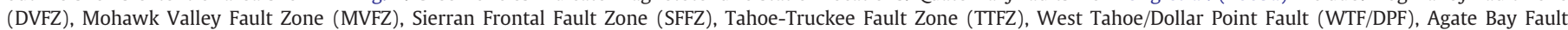
(ABF), North Tahoe Fault (NFT), Incline Valley Fault (IVF). 
a downstream drainage blanket on the west abutment, downstream seepage control features, an outlet works conduit, and a detached concrete-lined spillway cut into the slope about 300 meters west of the west abutment (Fig. 2a).

Martis Creek Dam has never held water to its designed gross pool level. Heavy seepage, primarily through the glacial outwash along the west abutment, has accompanied every reservoir fill test attempted (six from 1973 to 1995). Seepage studies suggest that a complex geometry of subsurface flow pathways must exist between the reservoir and the downstream slopes (USACE, 1996). Modifications over the years improved the ability of the downstream drainage blanket to handle seepage. However, a history of small sand boils around flowing relief wells at the downstream toe, slides along the downstream access road, heavy seepage in the vicinity of the outlet works, seepage and pin boils at the base of the downstream blanket, and seepage on either side of the spillway chute led to the decision to discontinue the last formal fill test in 1995 (USACE, 1996). Since then, the Martis
Creek Reservoir has been maintained at or below $1771 \mathrm{~m}$ (25\% of storage capacity) to mitigate the hazard associated with increased seepage at higher pool levels.

The motivation for the present study is to provide the USACE with the geologic, hydrologic, and structural background that is necessary to inform decisions on the future of Martis Creek Dam. This paper focuses on the near-surface basin structure and faulting hazards within the area. We apply an integrated suite of geophysical methods to investigate (1) subsurface controls on seepage, (2) the depth to crystalline basement, (3) the distribution and chronology of volcanic flows beneath the dam and reservoir, and (4) faulting in the vicinity of the Martis Creek Dam. We emphasize the importance of understanding the regional-scale geologic framework to our interpretation of structure, faulting, and hydrogeology at an engineering scale. The geophysical studies described herein also inform investigations into the deeper structure of the Truckee Basin and have implications for the tectonic evolution of the region.
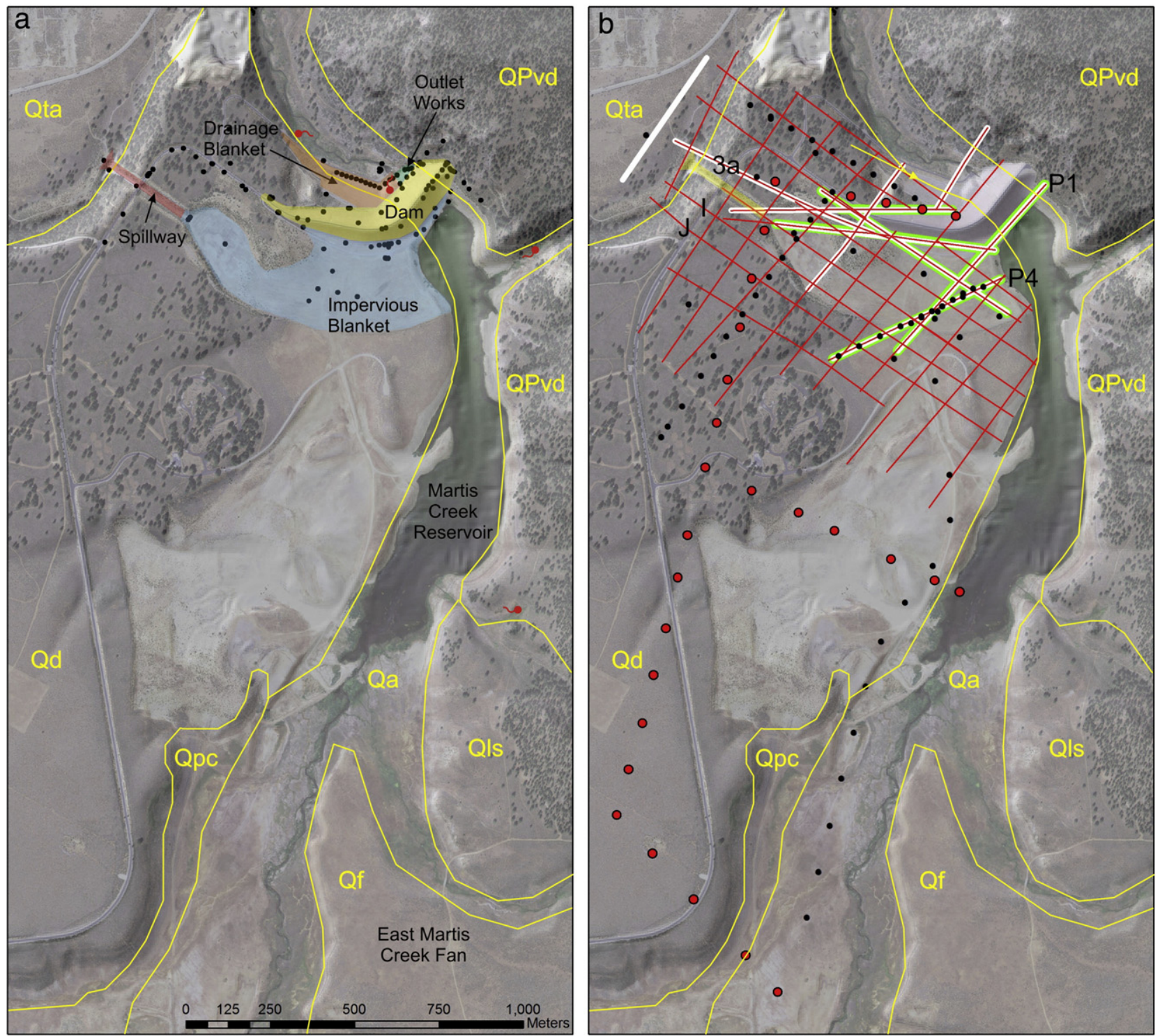

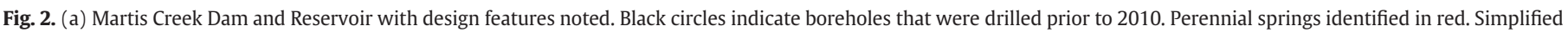

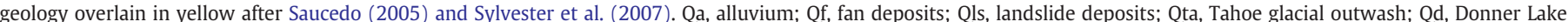

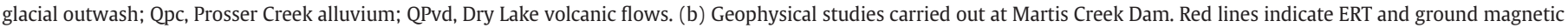

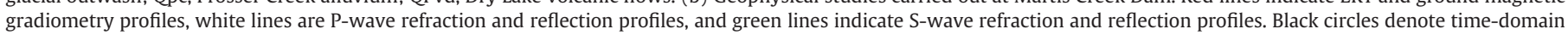
electromagnetic soundings, and red circles indicate 1966 DC resistivity soundings. 
Such investigations, however, are beyond the scope of this paper and will be presented elsewhere.

\section{Geologic background}

Martis Creek Dam is situated at an elevation of $1770 \mathrm{~m}$ within the southern Truckee Basin, which is bounded to the west by the 2750m-high Sierra Nevada Crest and to the east by the 3050-m-high Carson Range (Fig. 1). Part of the Sierra Nevada to Basin and Range transition, the Truckee Basin lies south of the Verdi-Boca Basin (Henry and Perkins, 2001) and to the north of the Lake Tahoe Basin. The present-day topography, including the Tahoe and Truckee Basins, is commonly accepted to have developed as the result of a major extensional event and uplift of the Sierra Nevada range that began around three million years before present (3 Ma) (Birkeland, 1961; Latham, 1985; Schweickert et al., 2004) and continues to this day (Hammond et al., 2011a,b).

Martis Creek Dam lies within a complex geologic framework. Glacial outwash deposits of variable thickness cover most of the region to an average depth of 20-30 m. The underlying Prosser Creek alluvium is at least $60-\mathrm{m}$ thick in the vicinity of the dam, and is underlain or interrupted by volcanic flows, based on lithology from a limited set of boreholes. The Prosser Creek alluvium is subdivided into an upper fluvial member (Qpcf), a lacustrine blue silt layer (Qpcl), and a lower lacustrine member (Qpcu). The dam itself rests upon the blue silt layer, which is deemed acceptable as an impermeable material essential to reservoir water retention (USACE, 1972). No sediments older than Prosser Creek (0.5-0.73 Ma, Latham, 1985) are mapped within the Truckee Basin, and the underlying volcanic flows are presumed to be Miocene and Pliocene in age. Exposed Miocene volcanic deposits lie directly atop Mesozoic Sierran basement at the edge of the Truckee Basin (Latham, 1985).

During the Miocene and Pliocene, at least six episodes of volcanism have affected the region. Major episodes of volcanism (with a volume over $100 \mathrm{~km}^{3}$, Cousens et al., 2008) include $12 \mathrm{Ma}$ andesitic flows, tuffs, and breccias that blanket much of the region and 3-5 Ma andesitic to basaltic flows to the north (Boca Hill) and west (Squaw Peak, Twin Peaks) of Lake Tahoe. A less voluminous period of andesitic volcanism between 8 and 6 Ma was focused around Martis Peak and Mount Lincoln (Cousens et al., 2008). Around the onset of extension at $3 \mathrm{Ma}$, a number of localized basaltic centers reshaped the area to the north of Lake Tahoe, though there is disagreement regarding whether the basaltic volcanism predates (Poole and Daley, 1949; Hudson, 1951; Louderback, 1924) or postdates the onset of extension (Birkeland, 1963; Latham, 1985; Thompson and White, 1964).

The northern portion of Martis Creek, and the east abutment of the Martis Creek Dam follow the west edge of the Dry Lake volcanic flows (DLV, QPvd), part of a long-lived volcanic center which produced between four (Birkeland, 1961) and six (Latham, 1985) distinct flows (Fig. 2). Downstream of the dam, near the intersection of Martis Creek with the Truckee River, the west edge of a DLV flow is mapped as a down-to-the-west normal fault (Birkeland, 1963; Latham, 1985), whose southward projection is aligned with the West Tahoe-Dollar Point Fault, a major down-to-the-east normal fault zone associated with formation of the Lake Tahoe Basin (Fig. 1). Five kilometers west of the Martis Creek Dam, the normal-dextral down-to-the-east Tahoe-Truckee Fault Zone (Olig et al., 2005b) transfers strain between the Mohawk Valley Fault Zone to the northwest and the West TahoeDollar Point Fault.

Downstream of the Martis Creek Dam, one or more of Pleistocene basaltic flows are believed to have blocked the drainage of the Truckee River, the only outlet of Lake Tahoe, resulting in deposition of the fluvial and lacustrine Prosser Creek alluvium (Qpc; Fig. 2) found throughout the Truckee Basin (Birkeland, 1963; Lindgren, 1897). Alternatively, Louderback (1906) proposed that the Prosser Creek alluvium was deposited in response to tectonic uplift, and paleomagnetic studies by Latham (1985) provide evidence in support of this interpretation. Deformation since the cessation of volcanism has been minor, resulting in tilting of the Prosser Creek alluvium by $2-3^{\circ}$.

Multiple glacial episodes are recognized in the region (Birkeland, 1964); one of the most widespread was the pre-Wisconsin age (0.5 Ma) Donner Lake glaciation (Birkeland and Janda, 1971), which left behind a thick outwash blanketing parts of the Truckee Basin. This material was subsequently cut by the smaller Tahoe glacial event which melted and filled many of the smaller valleys between 56,000 and 118,000 years ago (Yount and LaPointe, 1997). At the Martis Creek Dam site, Donner Lake outwash (Qd) is at the surface from the creek valley across the west abutment to the top of the spillway (Fig. 2). At the base of the spillway, Tahoe outwash (Qta) fills the broad valley that extends toward the Truckee River. The Donner glacial outwash material covers the previously faulted and eroded surface of the older Prosser Creek deposits. Both the Donner Lake outwash and the Prosser Creek alluvium are highly variable in nature, with significant material property changes both vertically and laterally. In general, the much older Prosser Creek alluvium, with higher clay content and a greater degree of consolidation, has relatively low hydraulic conductivity, while the younger, lower clay content Donner Lake outwash has much higher hydraulic conductivity (Cedergren, 1976).

Though numerous faults are mapped within the region, faulting in the immediate vicinity of the Martis Creek Dam is largely unknown. Early mapping by Birkeland (1963) suggests the north-south trending fault that cuts the DLV to the north of the dam continues southward beneath the east dam abutment. Latham (1985) further argues for approximately $30 \mathrm{~m}$ of dip-slip movement along this fault since 1.3 Ma. Recent light detection and ranging (LiDAR) investigations (Hunter et al., 2011) show evidence for a previously undiscovered dextral strike-slip fault near the dam spillway, as well as along the East Martis Creek Fan south of the Martis Creek Reservoir (Fig. 2).

\section{Data acquisition and processing}

The structural setting of the Martis Creek Dam area has been studied through a combination of geophysical methods, including electrical resistivity tomography (ERT), seismic refraction and reflection, time-domain electromagnetic sounding (TEM), ground and airborne magnetic field surveys, and magnetotelluric sounding (MT) (Fig. 2). A brief description of each of these techniques as applied to this study follows.

a) ERT imaging. During three phases of acquisition in 2008 and 2009, a total of 28 two-dimensional (2-D) ERT profiles were collected at Martis Creek Dam (Fig. 2b). All data were acquired using a SuperSting R8 resistivity/IP meter by Advanced Geosciences, Inc. An inverse Schlumberger array, defined by a linear geometry with two current electrodes centered symmetrically between two potential electrodes, was used. The inverse Schlumberger array is an efficient use of a multi-channel resistivity meter because multiple potential electrode pairs can be measured simultaneously using a single current electrode pair. This array type was chosen over the dipoledipole array, because it generally provides higher signal levels for the deeper measurements and is more sensitive to resistivity variations with depth (Loke, 2010). A maximum of 120 electrodes were used for each layout, with a typical electrode spacing of $5 \mathrm{~m}$. For lines longer than the maximum 120-electrode layout, subsequent 'roll-alongs' of at most 28 electrodes were performed until the total desired line length was achieved. This survey configuration was designed to provide a maximum depth of investigation of about $100 \mathrm{~m}$. The data were processed to produce 2-D resistivitydepth sections using a robust inversion method that minimizes an L1 norm of combined data misfit and model regularization (Advanced Geosciences, Inc., 2008) and incorporates topographic 
information obtained from a real-time kinematic (RTK) global positioning system (GPS) unit.

In addition to the $2-\mathrm{D}$ profile data, 28 Wenner array, onedimensional (1-D) direct-current (DC) resistivity soundings were recorded by a contractor in 1966 prior to dam construction (GeoRecon Inc., 1966). These soundings employed a maximum electrode spacing of $50 \mathrm{~m}$, roughly equivalent to the maximum depth of investigation, and were reduced by the contractor to $1-\mathrm{D}$, minimum-layer models.

b) Seismic refraction and reflection. The seismic acquisition procedure was designed to provide excellent coverage for seismic refraction tomography, as well as good reflection coverage if coherent reflection arrivals were recorded. The refraction surveys were conservatively designed to investigate the top 60 to $100 \mathrm{~m}$ for this project. Coherent reflected energy was recorded throughout most of the survey area.

The seismic profiling utilized a linear array of geophones planted at regular intervals. A variety of seismic sources including a $200-$ $\mathrm{lb}$, trailer-mounted accelerated weight drop (AWD) source, a manual sledgehammer, and $1 / 3-\mathrm{lb}$, buried explosive charges were used during data acquisition. Four to six Geometrics Geodes with 24 active channels each were used together for arrays of 96 or 144 channels. The Geodes have 20-bit sampling and were set to 0.25 or 0.5 millisecond sampling interval, and 1.0 or 2.0 second record length for compressional wave ( $\mathrm{P}$-wave) and shear wave (S-wave) acquisition, respectively. Geophone spacing for both $\mathrm{P}$ and S-wave surveys was nominally $5 \mathrm{~m}$. Seismic sources were located between every other geophone position.

With the AWD and sledgehammer sources, multiple vertical strikes per source position were stacked to create a single, highquality shot record. For S-wave energy, the same combination of AWD source and manual sledgehammer were used, but impacts were horizontal and directed perpendicular to the profile at steel plates spiked to the ground. Independent S-wave shots were collected with opposite polarity (from either side of the profile) to permit subsequent separation of compressional and shear wave energy arrivals. This separation was carried out by reversing the polarity of one of the shots and then summing it with a shot of opposite polarity. The refraction tomography velocity-depth sections are created by an inversion process that accounts for the survey geometry and the first-arrival times. We used a combination of inversion algorithms (Schuster and Quintus-Bosz, 1993; Zhang and Toksoz, 1998) with various starting models and parameters to produce our final velocity images.

Reflection imaging provides much higher resolution than refraction tomography in defining interfaces that correspond to vertical and lateral changes in subsurface properties. Reflection imaging, however, involves many steps toward the creation of an accurate image of subsurface features. The most important steps include (1) the determination of accurate acquisition geometry, (2) accounting for energy lost due to geometrical divergence and material attenuation, (3) frequency filtering to reject noise, (4) source-signature spectrum balancing to regularize the source pulse shape, (5) static time shifting of traces, (6) the sorting of traces according to the common midpoint location of the shot and receiver, (7) the determination of laterally changing velocity functions, (8) the summation of the common-midpoint-gathered traces, and (9) post-stack filtering, static corrections, and conversion from time to depth. The resulting images show the spatial position and lateral continuity of subsurface property interfaces; these images are subsequently interpreted to identify probable fault locations, dipping strata, and the thickening, thinning, and/ or pinching out of shallow depositional layers.

c) Time-domain electromagnetic sounding. TEM soundings provide a focused one-dimensional resistivity model of the subsurface. In most applications, the TEM method is sensitive to deeper structure than ERT imaging (upper $100 \mathrm{~m}$ ) and shallower than magnetotelluric sounding (typically greater than $500 \mathrm{~m}$ ). Central-loop TEM soundings were acquired at 52 locations using a square transmitter loop in combination with either a Zonge GDP-32 system or a Geonics ProTEM system. The depth of penetration scales with the transmitter loop size, which was either $50 \mathrm{~m}$ on a side (soundings along profile $\mathrm{P} 4$ and along the downstream profile; Fig. $2 \mathrm{~b}$ ) or $100 \mathrm{~m}$ on a side (soundings on remaining upstream profile and scattered soundings). The depth of investigation is roughly 2 to 3 times the loop dimension, which translates into penetration depths of up to $300 \mathrm{~m}$. A single $300-\mathrm{m}$ transmitter loop sounding was also acquired atop the upstream drain blanket to evaluate deeper basin structure. The TEM method induces a current in the subsurface by rapidly turning off current in the surface transmitter loop. Data at all sites consist of a time-decaying voltage measured in the receiver coil; this voltage is proportional to the vertical component of the time derivative of the induced magnetic field. Data were recorded from $10 \mu$ s to $10 \mathrm{~ms}$, which were then averaged, trimmed relative to measured noise levels, converted to apparent resistivity values, and subsequently modeled and inverted. All inversion and modeling were done within the SiTEM/Semdi inversion suite, a TEM analysis package which permits full current-waveform modeling, a rigorous treatment of data errors, and the incorporation of prior information during inversion.

d) Magnetic field surveys. Airborne magnetic field data were collected in June 2008 over a $142 \mathrm{~km}^{2}$ area centered roughly on the Martis Creek Dam (Fig. 1). Data were collected by Aeroquest Ltd. using a Geometrics G-823A cesium vapor magnetometer (0.01 nanoTesla (nT) sensitivity) mounted on a boom located between the skids and extending forward from the helicopter. Airborne total magnetic field data were collected in conjunction with a GPS navigation system and a radar altimeter; ground-level total magnetic field data were collected at a fixed base station magnetometer. The total survey coverage consists of 934 line-km, flown in an east-west line direction with nominal 200-m line spacing and draped over topography at a $150 \mathrm{~m}$ nominal altitude. An along-line sampling interval of approximately $3.5 \mathrm{~m}$ resulted from an average airspeed of $130 \mathrm{~km} / \mathrm{hr}$ and a 0.1 -sec sampling interval. In addition to the main survey block, an infill area of $10 \mathrm{~km}^{2}$ centered about the dam was flown, with a $100-\mathrm{m}$ line spacing and a nominal $60-\mathrm{m}$ altitude. The survey terrain is mountainous, with elevations ranging from 1650 to $2460 \mathrm{~m}$ above sea level.

Recorded data were compensated for airframe movement, and diurnal drift was subsequently removed using magnetic field base station data. The regional International Geomagnetic Reference Field 2000 was removed from the data, computed using the GPS location and elevations at each observation point. The geophysical data were interpolated onto a regular grid with a cell size equal to half the line spacing using a minimum-curvature interpolation technique. The grid was then filtered to remove east-west lineations produced by residual flight-line leveling noise, a process known as de-corrugation. Reduction-to-pole (RTP) filtering was subsequently applied to the aeromagnetic data to center the anomalies over their sources. This filter used a geomagnetic inclination of $63.1^{\circ}$ below horizontal and a declination of $14.5^{\circ}$ east of north. The resulting RTP total magnetic field grids were finally terraced to emphasize the first-order variations within the survey region.

Ground-based magnetic field data were acquired in March 2008 along the East Martis Creek fan, located south of the Martis Creek Reservoir (beyond the southeast corner of Fig. 2). Additional data were acquired in June 2009 along 17 of the 28 ERT profiles. The instrument was a Geometrics G-858 cesium vapor magnetometer in vertical gradiometer mode at a sample rate of $10 \mathrm{~Hz}$ and integrated with a RTK GPS system. Base station total magnetic field data were acquired by a Geometrics G-856 proton precession 
magnetometer at a $0.03-\mathrm{Hz}$ sample rate for the March 2008 dataset and by a GEM Systems GSM-19 Overhauser magnetometer at a 0.3-Hz sample rate for the June 2009 dataset. Diurnal drift has been removed from the final data.

e) Magnetotelluric sounding. The MT method exploits time variations of the electric and magnetic fields recorded at the Earth's surface to constrain subsurface resistivity on scales of hundreds of meters to tens of kilometers. MT data were acquired at 30 sites along a $20-\mathrm{km}$, east-west profile centered about the south end of the Martis Creek Reservoir (Fig. 1). Data were acquired using four synchronously recording EMI MT24 instruments, where each station recorded horizontal electric and magnetic field variations as well as vertical magnetic field variations for 20 hours on average. Data were processed using the multi-station, remote-reference algorithm of Egbert (1997) to produce MT response functions in the range of $10^{2}-10^{-3} \mathrm{~Hz}$. Modeling and inversion of the data were performed in two dimensions using the regularized inversion algorithm of Rodi and Mackie (2001).

f) LiDAR. The US Army Corps of Engineers purchased approximately $25 \mathrm{~km}^{2}$ of LiDAR data from the Truckee-Donner Public Utility District to generate a high-resolution $(0.6 \mathrm{~m})$ digital-elevation model to support geotechnical investigations, evaluate surface morphology, and provide data for potential inundation modeling. These maps show evidence of late Pleistocene and Holocene faulting within the Martis Creek area as described in detail within Hunter et al. (2011).

\section{Results and discussion}

\subsection{Hydrogeology}

The boundary between the Donner Lake outwash and the Prosser Creek alluvium is a prominent change from high hydraulic conductivity to low hydraulic conductivity, respectively (Cedergren, 1976). The two-dimensional ERT models (e.g., Fig. 3a) reveal a strong contrast between the base of the resistive Donner Lake outwash ( $>250 \mathrm{ohm}$ meter, $\Omega \mathrm{m}$ ) and the top of the less resistive Prosser Creek alluvium $(<100 \Omega \mathrm{m})$ that is observed on nearly all profiles. In order to map this interpreted lithologic boundary throughout the survey area, the correlation between the ERT models and borehole lithology was investigated. Upon examining 48 boreholes in close proximity to the ERT profiles, a $200 \Omega \mathrm{m}$ resistivity contour was determined to most strongly correlate with the top of Prosser Creek alluvium (Qpcf). The mean difference between the top of Qpcf, as determined from the boreholes, and the depth to the $200 \mathrm{ohm}$-meter contour, extracted from the ERT models, is $1.5 \mathrm{~m}$ with a standard deviation of $4.6 \mathrm{~m}$.

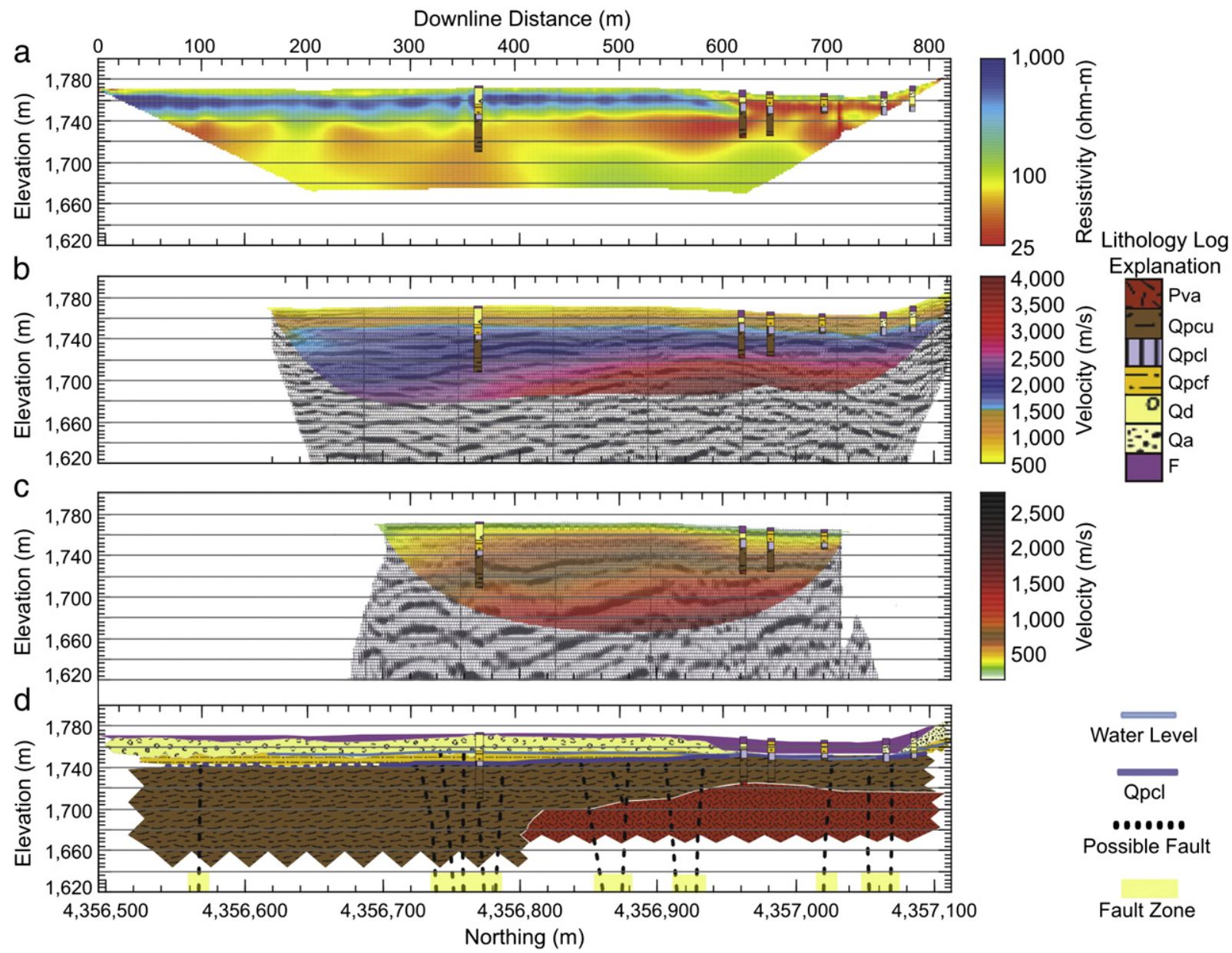

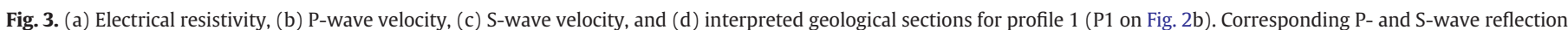

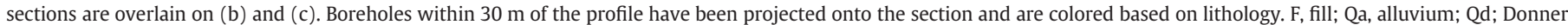

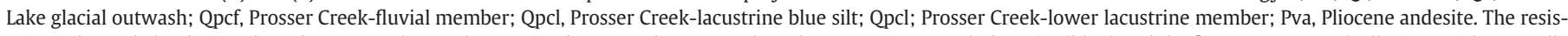

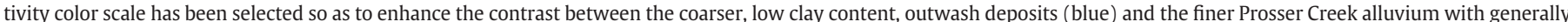

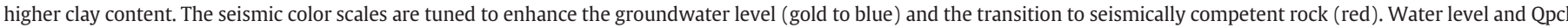

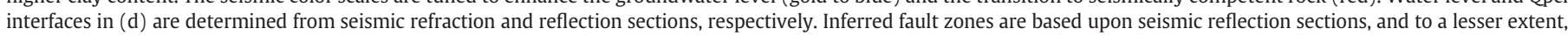
ERT data. 
The thickness of the glacial outwash varies smoothly throughout most of the survey area and pinches out at the west edge of the reservoir (e.g., $600 \mathrm{~m}$ downline on profile 1, Fig. 3a) and to the northeast, consistent with the mapped extent of the outwash (Fig. 2). Within the area covered by the resistivity profiles however, significant variation is observed in the thickness of the outwash deposits (Fig. 4). Where they overlap, the TEM resistivity models are in close agreement with ERT sections and extend the constraint on the base of the glacial outwash to the south. One-dimensional models from the 28 DC resistivity soundings acquired in 1966 also provide constraints to the southwest of the main survey area.

Within the Prosser Creek alluvium, the ERT sections indicate subhorizontal layering, with a low resistivity member $(10 \Omega \mathrm{m}$, approximately $30 \mathrm{~m}$ thick) overlying a slightly more resistive member. The ERT sections are limited in sensitivity to the upper $100 \mathrm{~m}$; however, the 52 TEM soundings, with their greater depth of investigation, constrain subsurface resistivity to more than $300 \mathrm{~m}$ depth, and without exception indicate low resistivity at these depths.

The groundwater level cannot be identified from the ERT and TEM models, suggesting that subsurface resistivity variations are primarily controlled by clay content rather than water saturation. P-wave seismic refraction models, however, recover the water level as a relatively flat-lying velocity contour at $1525 \mathrm{~m} / \mathrm{s}$. The selected velocity contour is consistent with the expected velocity range for saturated, un-compacted sediments (e.g., Reynolds, 1997). The water level, as interpreted from the seismic models, is verified in multiple locations with the water level in boreholes drilled and logged in 2007, when the reservoir was at a level comparable to that at the time of the seismic surveys. Furthermore, the water level was interpreted independently on each P-wave refraction profile, and fits well at profile intersections. On average, the water level is at an elevation of $1753 \mathrm{~m}$, with the most significant variations mimicking surface topography along the east abutment and below the spillway. The water level, however, cuts across the Donner Lake outwash-Prosser Creek alluvium interface, but remains consistently at or above the blue silt horizon $(\mathrm{Qpcl})$ defined from the seismic reflection sections and confirmed by test hole data (e.g., Fig. 3). This indicates that the blue silt member within the Prosser Creek alluvium is acting as an aquitard for groundwater within the survey area. The groundwater level is depressed relative to the reservoir, which at the time of
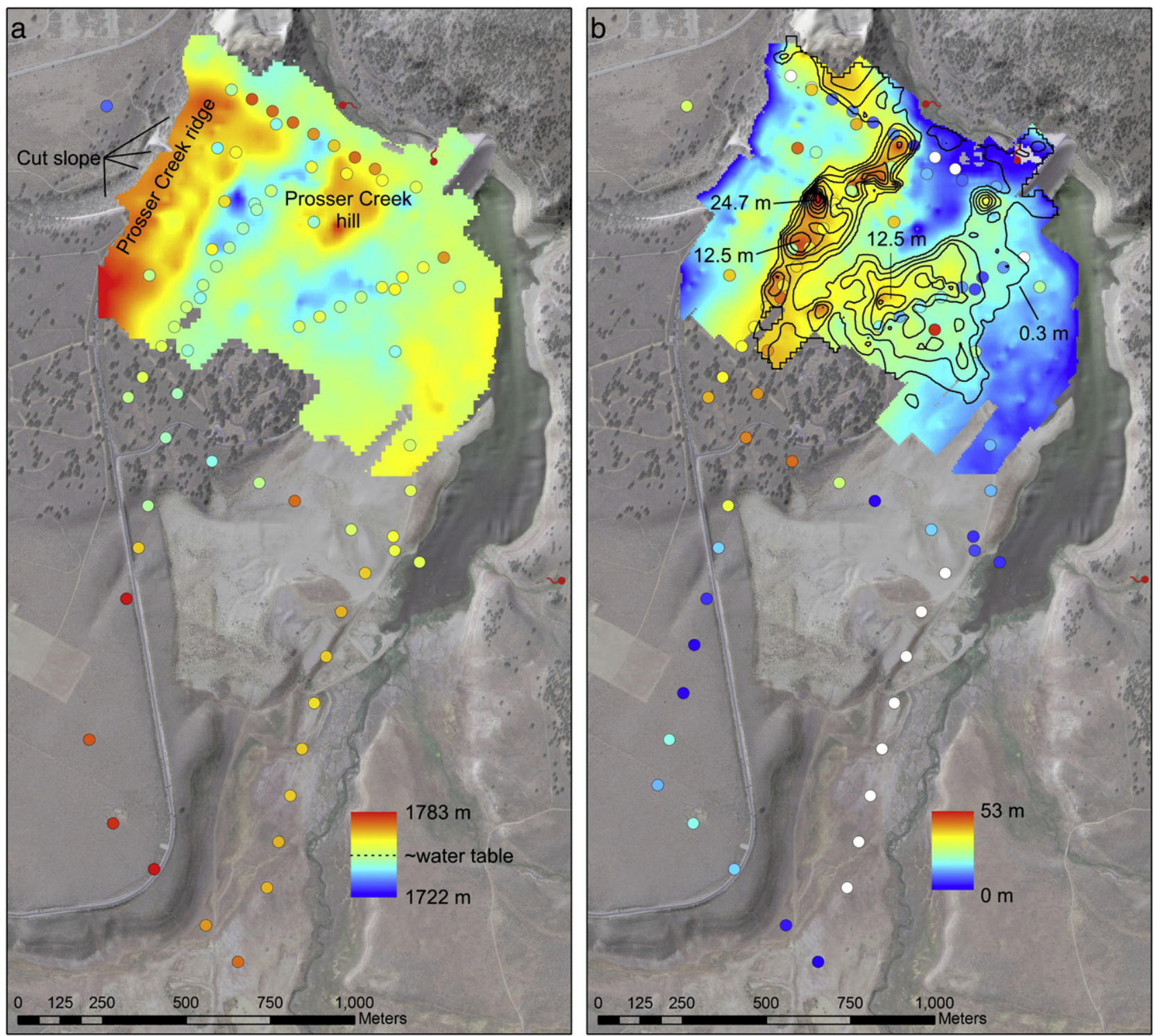

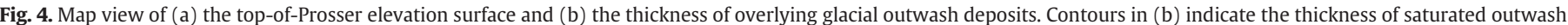

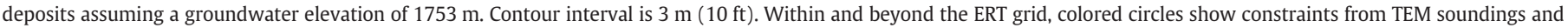

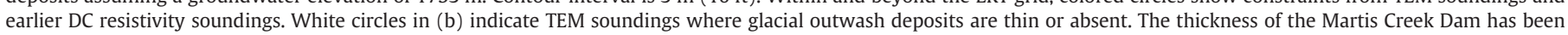
removed from the isopach map in (b). 
these surveys was maintained at $1763 \mathrm{~m}$. As will be discussed in the next section, the relationship between reservoir level, groundwater level, and the Prosser-outwash contact is a primary control on the seepage behavior observed during test fills.

The $200 \Omega \mathrm{m}$ resistivity contour has been traced through the ERT model sections and then gridded to generate the surfaces shown in Fig. 4. We interpret these surfaces as the interface between the Prosser Creek alluvium and the overlying Donner Lake glacial outwash deposits. The elevation surface (a) and the derived isopach map (b) reveal two thick outwash packages with NNE and ENE trends. These are interpreted as paleochannels incised within the Prosser Creek alluvium and are separated from one another by a high ('the hill') situated beneath and to the south of the left dam abutment. This high rises more than $45 \mathrm{~m}$ above the surrounding channels. The paleochannels are also confined to the west by an elongated Prosser high ('the ridge') that is parallel to the cut-slope that forms the west edge of the Donner Lake outwash. The paleochannels appear to converge at the south end of the ERT grid, and continue for at least $500 \mathrm{~m}$ south of the grid based upon TEM soundings and the 1966 DC resistivity soundings. Beyond this point, the paleochannel may extend further west, however, the geophysical data indicate that it does not extend further south or east.

The topography of the outwash-alluvium interface and its relation to groundwater level is of primary importance in understanding the hydrogeology of the area; this interface separates poorly sorted boulder and gravel cobbles, silts, and sands from cemented and indurated gravels, sands and silts. A high hydraulic conductivity $(0.35 \mathrm{~cm} / \mathrm{s})$ has been estimated for the glacial outwash based on discharge and hydraulic gradient data from past test fills (Cedergren, 1976). Quantitative estimates of the hydraulic conductivity of the Prosser Creek alluvium are not available, however drawdown tests within the upper (outwash) and lower (Prosser Creek) aquifers note a significantly slower rebound within the lower aquifer (USACE, 1966), suggesting a much lower hydraulic conductivity within the Prosser Creek alluvium. Thus, given sufficient hydraulic head, the outwashfilled paleochannels are expected to act as conduits for focused groundwater flow.

The origin of the paleochannels both inside and outside of the study area is unclear. The Prosser Creek alluvium was recognized by Lindgren (1897) as a lake and lake-margin deposit and Lindgren postulated that it formed in response to damming of the Truckee River drainage by lava flows. Birkeland (1963) identified the extrusion of the Hirschdale latite, one of the youngest of the Pleistocene volcanic flows ( $\mathrm{K}-\mathrm{Ar}$ age date of $1.3 \mathrm{Ma}$ ), as the causative event; although this interpretation has been called into question by Latham (1985) who argues that the Prosser Creek alluvium was deposited in response to tectonic uplift. Regardless of the origin of the Prosser Creek alluvium, the eventual reestablishment of the Truckee River (and Martis Creek) through the region presumably triggered the transition from lacustrine (Qpcl, Qpcu) to fluvial (Qpcf) deposits that is observed within the Prosser Creek alluvium. It is plausible that the paleochannels, located between the present-day Martis Creek and the Truckee River, represent former channels of this river system prior to glaciation. The Donner Lake and Tahoe glacial episodes may subsequently have rerouted the Truckee River and Martis Creek to their present-day locations. Alternatively, the paleochannels may have formed as tunnel valleys during the extensive Donner Lake glaciation, though such valleys are more commonly associated with the margins of continental ice sheets rather than the alpine glaciation which occurred in this region (Birkeland, 1964).

\subsection{Paleochannels and water seepage}

The groundwater level of $1753 \mathrm{~m}$, as determined from the seismic refraction models, is combined with the top-of-Prosser elevation surface in Fig. 4a to create contours of saturated aquifer thickness
(Fig. 4b). These contours, however, represent a minimum estimate of the true saturated aquifer thickness, because the uppermost Prosser Creek deposits, above the blue silt member, should also be included within the upper aquifer. Regardless of this omission, it is clear that the reservoir is hydraulically connected through the glacial outwash channels to the downstream side of the Martis Creek Dam.

At groundwater levels of $1753 \mathrm{~m}$ or higher, two distinct pathways of saturated (high hydraulic conductivity) outwash connect the regions upstream and downstream of the dam. Reservoir waters can short circuit the dam and flow around the left embankment through the western paleochannel, emerging in the vicinity of the downstream drainage blanket, rebuilt in 1976-77 and extended in 1985 specifically to deal with seepage. The eastern paleochannel provides a secondary groundwater flow path that crosses directly beneath the dam to the west of the outlet works. According to the dam foundation report (USACE, 1972), the dam embankment was built upon a surface excavated down to the impervious blue silt, however several lines of evidence suggest that at best a partial barrier to groundwater flow exists in this region. The downstream exit of this pathway sits atop a natural spring that was encapsulated into the downstream toe of the dam during construction. A marked increase in discharge from this spring and another spring $300 \mathrm{~m}$ downstream was noted during past test fills (USACE, 1996). In light of the geometry of the outwash paleochannels, it is likely that this spring is fed by regional northeastly flowing groundwater within the outwash paleochannels. Furthermore, a line of temperature-monitoring wells along the upstream edge of the dam revealed two regions of cold water that developed during the course of the 1995 test fill. These cold water zones, which correspond spatially to the two pathways illuminated in Fig. 4, are inferred to be the result of increased subsurface flow due to the increased reservoir head (GSI, 1995). Finally, outflow from the pathway beneath the dam is consistent with known seepage beneath the downstream drain blanket.

It is important to emphasize that at a reservoir level of $1763 \mathrm{~m}$, far below the designed gross pool level $(1784.3 \mathrm{~m})$ as well as below the current $1770.9-\mathrm{m}$ maintenance level, the approximately $1753-\mathrm{m}$ groundwater level is such that groundwater is hydraulically connected around and beneath the dam. This elevation represents an equilibrium between surface water and groundwater input to the upstream catchment, and outflow from the catchment through a combination of seepage and flow through the outlet works. Any increase in the reservoir level results in an increased hydraulic head which drives increased seepage beneath and surrounding the dam.

The seepage patterns that accompanied past test fills are qualitatively and quantitatively explained by the topography of the Donner Lake outwash-Prosser Creek alluvium surface. Seepage at low pool elevations (1767.8 to $1771.8 \mathrm{~m}$ ) has occurred around the west abutment of the dam while at higher pool elevations (1777.9 m) seepage also occurred along the cut slope that is adjacent to the spillway chute and along the downstream side of the east abutment (USACE, 1996). At very low groundwater levels (less than $1753 \mathrm{~m}$ ), the western-most outwash-filled paleochannel becomes isolated from the Martis Creek Reservoir by the Prosser hill beneath the west abutment (Fig. 4a). However, even at summer low water levels, such as during our geophysical surveys, a groundwater level of $1753 \mathrm{~m}$ is maintained, and limited seepage occurs.

The seepage problem has been partially mitigated by constructing a drainage shaft and drainage berm near the outlet works and by building the downstream drain blanket (Fig. 2a). At higher reservoir pool, however, the rising groundwater level opens up new pathways and groundwater is transported far from the reservoir. Monitoring of the most recent test fill $(1995,1777.9 \mathrm{~m})$ revealed seepage emanating from the cut slope adjacent to the spillway chute at $1768.4-\mathrm{m}$ elevation that extended to higher elevations as the reservoir pool increased. Upon drawdown, seepage in the spillway area ceased when the reservoir level dropped below $1773.6 \mathrm{~m}$. This seepage pattern 
suggests that the interface between the outwash and the Prosser Creek alluvium is at or near $1768.4 \mathrm{~m}$ adjacent to the spillway, and that groundwater levels during the test fill were elevated to at least this level. These observations are consistent with the resistivity profiles closest, and parallel, to the spillway chute that image the Donner Lake outwash-Prosser Creek alluvium contact terminating at the slope surface in the range of 1769 to $1771 \mathrm{~m}$ (Fig. 5). The resistivity profiles also indicate an elevated ridge of Prosser Creek alluvium within $150 \mathrm{~m}$ of the cut slope that acts as a barrier to westward groundwater flow until groundwater levels reached 1774.0 to $1776.0 \mathrm{~m}$. The lowest point along the Prosser ridge $(1774 \mathrm{~m})$ is located along the profile closest to the spillway (Fig. 5a). Both the elevation of this ridge and the subtle saddle near the spillway are consistent with the 1995 fill test observations and may explain why additional seepage was not observed along other sections of the cut slope at greater distance from the spillway.

\subsection{Depth to basement}

Prior to construction of the Martis Creek Dam, the interbedding of Prosser Creek sediments with Dry Lake volcanic flows was observed in boreholes along the east abutment (USACE, 1966). What was not known, however, was the extent to which these flows continue westward into the basin, nor the overall depth of the Martis Valley basin itself. Prior to this study, basement was assumed to be volcanic rocks that were penetrated by USACE boreholes at depths of 60 to $100 \mathrm{~m}$. Four water wells within $3 \mathrm{~km}$ of the survey area extend to $300 \mathrm{~m}$ depth, and indicate an alternating sequence of competent volcanic rocks and weathered volcanic breccias, but encounter no deep sediments of non-volcanic origin. The volcanic rocks, presumed to

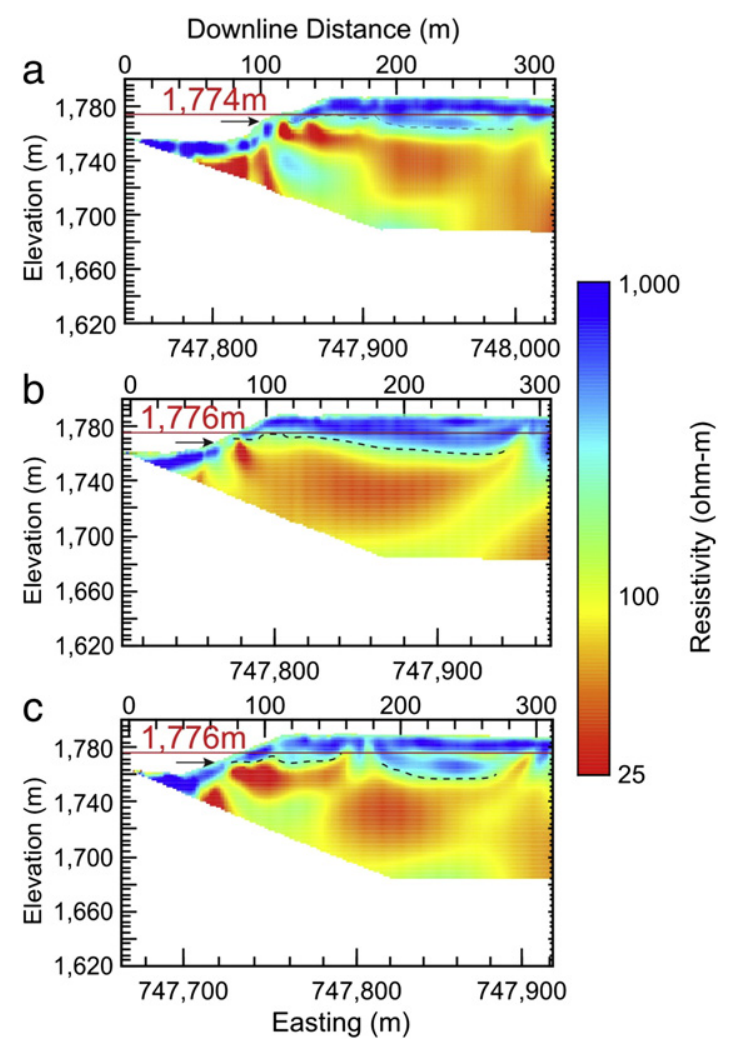

Fig. 5. West end of ERT sections along profiles 3a (a), I (b), and J (c) near the Martis Creek Dam spillway. Black dashed lines show the interface between the Donner Lake outwash and Prosser Creek alluvium. Red lines indicate the maximum elevation of the Prosser Creek ridge (Fig. 4a) along each profile. Black arrow indicates elevation $(1768 \mathrm{~m})$ at which seepage was observed along the cut slope during the 1995 test fill. be Miocene in age, were thought to lie directly on Mesozoic Sierran basement based upon structural relationships at the edge of the Truckee Basin (Latham, 1985). Our studies revise the understanding of the Martis Valley Basin considerably.

Of the 121 boreholes drilled within the USACE property through the end of 2009, 12 encountered volcanic rock at depth. These boreholes are distributed along the east abutment, downstream of the dam on the west side of Martis Creek, and along the road connecting the spillway to the dam. Only one of the 12 boreholes, however, was drilled more than $3 \mathrm{~m}$ into volcanic material. Based upon this limited borehole sampling, the top of the volcanic deposits is located at elevations ranging from $1675 \mathrm{~m}$ to greater than $1730 \mathrm{~m}$. Assuming minimal vertical displacement since their emplacement, the $55-\mathrm{m}$ variation in flow elevation over the $1 \mathrm{~km}^{2}$ area containing the boreholes suggests the presence of multiple overlapping volcanic flows.

P-wave refraction tomography sections image a high-velocity layer $(>3000 \mathrm{~m} / \mathrm{s}$ ) on several profiles (e.g., Fig. 3b) attributed to one or more volcanic flows. Nearby profiles (e.g., profile 4, Fig. 6) are located adjacent to, but not directly above the inferred flows, and the corresponding refraction models do not resolve a highvelocity layer. Where the refraction profiles are in close proximity to boreholes, the presence or absence of high-velocity features is in close agreement with borehole lithology. Similar to the borehole data, the seismic refraction sections also indicate significant variation in the elevation of the top of the high-velocity layer, ranging from 1630 to $1725 \mathrm{~m}$. There are also indications in the ERT sections of a more resistive layer at depth (relative to the less resistive overlying Prosser Creek alluvium) that correlates spatially with the volcanic flows observed in the borehole data and the high-velocity layers in the P-wave refraction sections (e.g., Fig. 3a). In contrast, the TEM soundings show no indication of the presumed resistive volcanic flows, which reflects a general insensitivity of the TEM method to thin resistive layers. Modeling indicates that a resistive layer whose thickness is less than its depth is virtually undetectable when embedded in a low resistivity background.

The seismic tomography models image the top of one or more highvelocity bodies inferred to be volcanic flows, but provide little resolution at greater depth. P- and S-wave seismic reflection sections, however, show evidence of layering at depths below that of the high velocity bodies. One section in particular (profile 4, Fig. 6b) shows coherent flat-lying reflections at depths up to $200 \mathrm{~m}$. These coherent reflections are only observed in regions where the refraction tomography does not image a high-velocity body. This is consistent with the high degree of scattering expected from the volcanic flows; where absent, reflections from deeper stratigraphic layering are resolved.

The TEM models indicate low resistivities $(\leq 10 \Omega \mathrm{m})$ at depths of 120-180 m throughout the area, providing independent evidence for deep stratigraphy. The top of the low-resistivity zone is more than $100 \mathrm{~m}$ below the groundwater level, although a deeper aquifer (below the blue silt) is known to exist (USACE, 1966). Nevertheless, we find it unlikely that the low electrical resistivity can be explained in terms of saturation alone, as pore fluids would have to be highly saline to produce the measured response. Furthermore, assuming pore fluids provide the dominant pathway for electrical conduction, a general decrease in porosity with increasing compaction would result in an increase in resistivity with increasing depth. This predicted trend is inconsistent with the observed trend in the TEM models which show decreasing resistivity with increasing depth. Given independent evidence of deep stratigraphic layering from the reflection sections, we attribute the deep region of low resistivity to one or more clay-rich zones within or below the Prosser Creek alluvium. Some or all of the clay may result from weathering of the inferred volcanic flows; this is consistent with driller's logs from nearby water wells, which report intervals of highly weathered volcanic rock. 


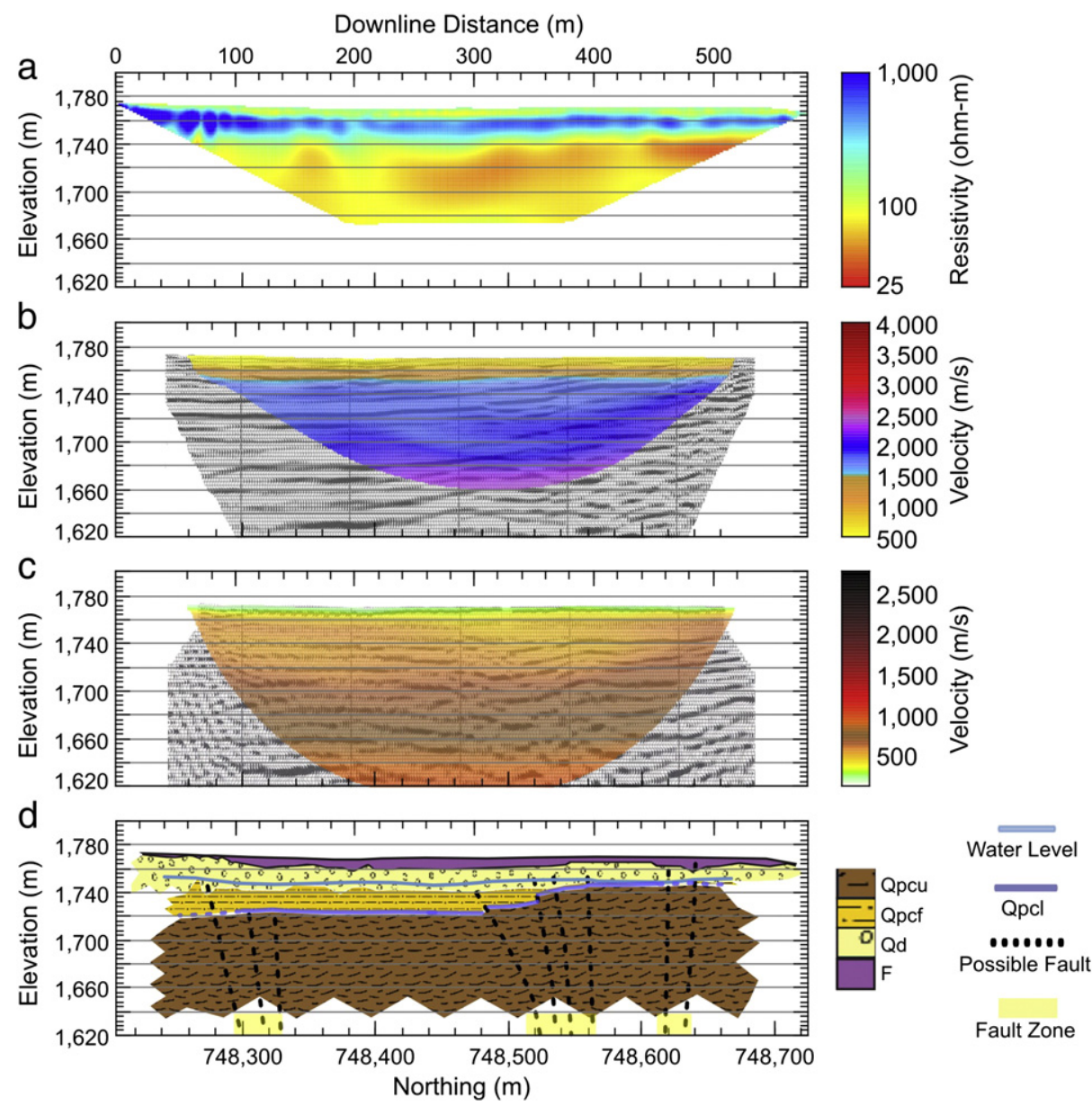

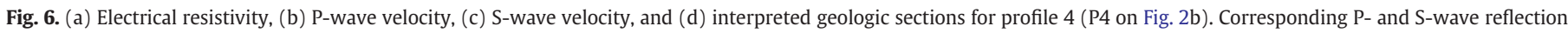

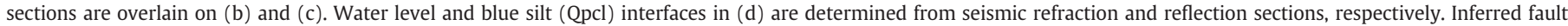
zones are based upon seismic reflection sections, and to a lesser extent, ERT data.

Determination of the total depth of the Martis Creek Basin and the origin of the deep-basin sediments requires greater depth penetration and a more regional view. Examining the depth to the top of the low-resistivity layer, together with the distribution of TEM soundings reveals a $4^{\circ}$ northward dip, which if extrapolated to beneath the dam, implies a low-resistivity layer at greater than 550-m depth. To better examine the deep-basin structure, a large TEM transmitter loop, $300 \mathrm{~m}$ on a side, was laid out along the upstream drain blanket just west of the reservoir. The model derived from this sounding, which applied a transmitter moment of nearly $1,000,000 \mathrm{~A} \cdot \mathrm{m}^{2}$,

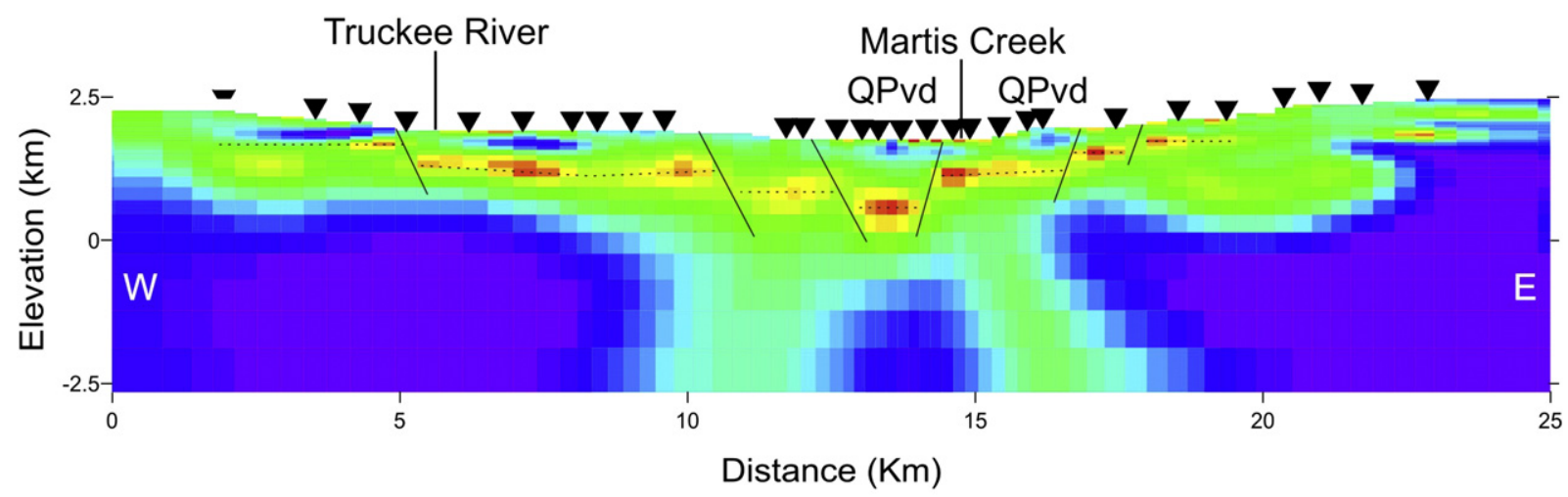

Resistivity (Ohm.m)

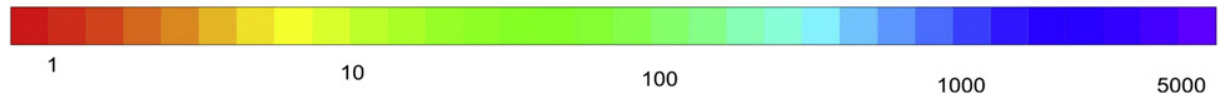

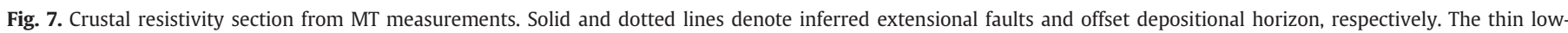
resistivity surface layer beneath Martis Creek represents the Prosser Creek alluvium, imaged in greater detail by the ERT and TEM measurements. Geology as in Fig. 2. 
images a thick section of low resistivity, and places a minimum depth to high-resistivity basement at $600 \mathrm{~m}$.

A magnetotelluric survey, the location of which is shown in Fig. 1, provides the necessary aperture (20-km profile length) to image the deep structure beneath the Martis Creek Dam and the greater Truckee Basin. The resulting 2-D resistivity model (Fig. 7) images a symmetric basin with low resistivity $(<200 \Omega \mathrm{m})$ material as thick as $2.5 \mathrm{~km}$ resting upon a highly resistive basement - most probably Sierran granite that forms the core of the Sierra Nevada and Carson Ranges. Volcanic flows, including some of considerable thickness, are imaged as sub-horizontal resistive units within the basin sediments. The low resistivities imaged by the TEM and ERT measurements are imaged in the MT model as a thin layer of low resistivity to the west of Martis Creek. Therefore, we conclude that the Martis Creek Dam and reservoir rest not upon $100 \mathrm{~m}$ of sediments, as originally thought, but upwards of $2.5 \mathrm{~km}$ of sediments interbedded with Miocene to Pleistocene volcanic flows.

We interpret the deep sediments of the Truckee Basin to be the ashes, sandstones, and conglomerates of the Mio-Pliocene Coal Valley Formation (Latham, 1985) exposed within the Verdi Basin to the north. We speculate that their lack of exposure in the Truckee Basin is due to concealment by the voluminous 3-5 Ma volcanism to the north (Boca Hill) and south (Squaw Peak) or the 6-8 Ma volcanism to the west (Mt. Lincoln) and east (Martis Peak).

\subsection{Volcanic flow chronology}

The airborne magnetic-field data are ill-suited for estimating depth-to-basement due to the high remanent magnetization associated with the numerous Miocene to Pleistocene volcanic centers in the area. The data do, however, provide valuable information regarding the volcanic flow configuration beneath the Martis Creek Dam and reservoir. The Plio-Pleistocene Dry Lake volcanic (DLV) flows, which form the east abutment of the Martis Creek Dam, consist of at least four overlapping andesitic and dacitic flows. The number and distribution of flows is not well established, and only one age date (1.34 Ma, (Saucedo, 2005)) exists at the southeastern edge of the volcanic center. Fig. 8 shows the terraced, reduced-to-pole magnetic field data overlain upon both the LiDAR-derived elevation model and the geology after Saucedo (2005). The youngest DLV flows (A in Fig. 8) are located to the north and south of Dry Creek which drains Dry Lake ( $2 \mathrm{~km}$ east of the Martis Creek Dam) and flows into Martis Creek Reservoir. These flows are characterized by a strong normal magnetization, and, as will be described later, are believed to have been extruded during the Bruhnes magnetic polarity epoch ( $0.78 \mathrm{Ma}$ to present). Vents for these flows can be identified from the LiDAR imagery as circular or elliptical topographic features. The limited extent of these flows, and their spatial relation relative to the vents are consistent with these being the 'last gasp' for the DLV, a high-viscosity (volatile-poor) extrusion of limited volume. The two A flows may have been originally connected but, if so, have been dissected by subsequent erosion along Dry Creek.

Underlying the A flows is an extensive flow exhibiting reverse magnetization (B in Fig. 8). This flow appears to have originated in the vicinity of Dry Lake. Flow B is interpreted to have extruded during the Matuyama reverse magnetic polarity epoch (2.59 Ma to $0.78 \mathrm{Ma}$ ) based on the eastward extent of the negative magnetic region, its relation to the flow boundaries mapped by Sylvester et al. (2007), and the age date reported in Saucedo (2005). Flow B underlies most of the dam and reservoir, and it is interpreted to have travelled several kilometers to the west from its source. A decrease in the strength of the magnetic-field anomaly away from the inferred source suggests an increase in depth of burial to the west. Beneath the dam, borehole data suggest that the top of this flow occurs at an elevation of approximately $1720 \mathrm{~m}$. In contrast, boreholes to the west of the Martis Creek
Dam and off the edge of the interpreted B flow encountered volcanic deposits at an elevation of $1695 \mathrm{~m}$.

The oldest Dry Lake volcanic flows interpreted from the magneticfield data ( $\mathrm{C}$ in Fig. 8) are the most extensive, can be traced at least $3 \mathrm{~km}$ from an inferred vent to the east, and are characterized by a weak positive magnetization, reflecting greater burial than the strong magnetization of the A flows. It is the $\mathrm{C}$ flow that we interpret at an elevation of $1695 \mathrm{~m}$ in the boreholes to the west of the Martis Creek Dam. The positive and negative magnetic-field regions correlate well with the lower and higher borehole elevations, respectively; this relationship is the primary evidence that the B flow is younger than the $\mathrm{C}$ flow. An abrupt change in the depth to the volcanic deposits in boreholes northeast of the spillway is inferred to reflect the presence of a fault in this area. This is discussed further in the following section.

The seismic P- and S-wave refraction models support this interpretation. The high velocity horizon (Vp>3000 m/s, Vs> $1050 \mathrm{~m} / \mathrm{s}$ ) imaged along the upstream toe of the dam (e.g., Fig. 3b) deepens steeply to the southwest (downline distance of $350 \mathrm{~m}$ ). We interpret this to be the edge of flow B which extends beneath the Martis Creek Dam. Excellent agreement is observed between the seismic velocity models and the borehole lithology, as seen in Fig. 3.

\subsection{Faulting}

LiDAR imagery has recently been used to identify the Polaris Fault, a young dextral fault at least $35 \mathrm{~km}$ long, which cuts through the survey area (Hunter et al., 2011). This fault is part of the Tahoe-Truckee Fault Zone (Fig. 1), the broad discontinuous zone of north- to northwest-striking faults that stretch between the Mohawk Valley Fault system to the north and the West Tahoe-Dollar Point faults to the south. The northern section of the Polaris fault coincides with the Sierra Nevada Fault Zone of Olig et al. (2005b) and its location is consistent with paleoseismic studies by Melody (2009).

Based on a progressive dextral offset of Pleistocene geomorphic features, Hunter et al. (2011) estimate late-Quaternary slip rates on the Polaris Fault at $0.4 \mathrm{~mm} / \mathrm{yr}$. Fig. 9 shows several locations just north of the dam spillway and to the south of the reservoir along the East Martis Creek fan where geomorphic expressions of faulting are identified in the LiDAR imagery. Along the East Martis Creek fan, ground magnetic field profiles further show abrupt changes in magnetic field strength, which together with the LiDAR imagery support the presence of two fault splays crossing the fan. In this same area, the airborne magnetic field data show offsets in the Dry Lake volcanic flows (B and C in Fig. 8) that are consistent with the location and dextral sense of motion on the Polaris Fault. These right-lateral offsets are in the range of 200-500 m, however the uncertainty in the age of the flows make it difficult to place more than maximum bounds on the slip rate. The $200-\mathrm{m}$ offset in the northern edge of the B flow, interpreted to have been extruded during the last reverse magnetic polarity epoch $(>0.78 \mathrm{Ma})$, suggests a maximum late-Quaternary slip rate of $0.25 \mathrm{~mm} / \mathrm{yr}$. The southern edge of the older C flow (extruded during the previous normal magnetic polarity epoch) has $500 \mathrm{~m}$ of offset, which gives rise to a maximum Quaternary slip rate of $0.2 \mathrm{~mm} / \mathrm{yr}$. These findings are about half that of the LiDARderived slip rates and may indicate a slight increase in the slip rate on the Polaris fault throughout the Quaternary.

To the north of the spillway, the LiDAR evidence for faulting is consistent with offset stratigraphic horizons in nearby boreholes. Two boreholes separated by only $100 \mathrm{~m}$ distance show a vertical offset of $26 \mathrm{~m}$ in the elevation of the top of the Prosser Creek alluvium (Fig. 8); at least one strand of the Polaris fault is inferred to run between these boreholes. The Polaris Fault is undefined, however, along a two-kilometer stretch between the spillway and the East Martis Creek fan. We have used a combination of the seismic reflection and ERT sections to trace fault strands beneath the survey area. 


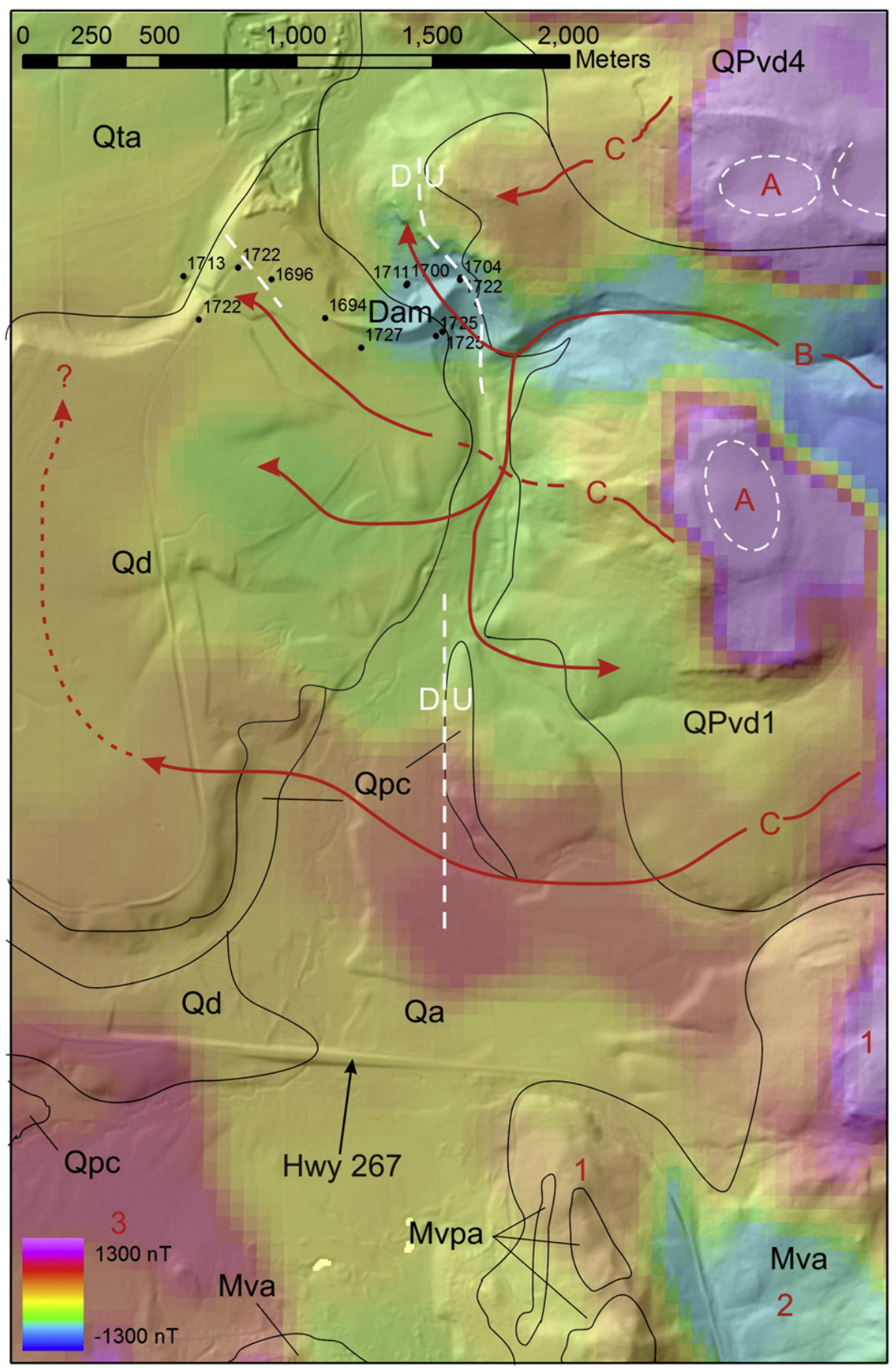

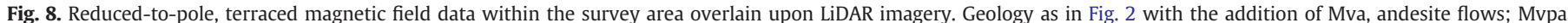

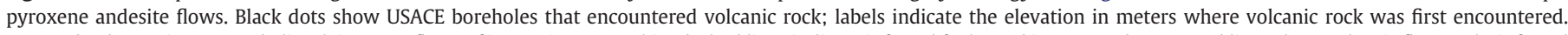

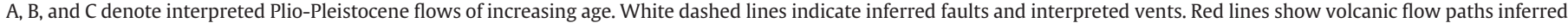
from the magnetic data.

The seismic reflection images show a number of offset reflectors, particularly within the Prosser Creek alluvium that are interpreted as evidence for Quaternary faulting. While individual faults are difficult to identify, zones of disturbed reflectors have been identified on each profile (e.g., $350 \mathrm{~m}$ distance downline in Figs. 3 and 6). Independently, the ERT models show occasional disturbances in the outwashProsser interface with a characteristic M-shaped appearance. An example can be seen along profile 1 at $350 \mathrm{~m}$ distance downline (Fig. 3a). A close correspondence exists between the seismically inferred fault zones and those identified from the ERT sections. We thus feel confident that these disturbed zones in the subsurface provide a means of identifying fault splays within the survey area (Fig. 9, solid red lines).

In addition to the Polaris fault is a north-south-trending, downto-the-west normal fault $2 \mathrm{~km}$ north of the Martis Creek Dam (Fig. 9). Birkeland $(1961,1963)$ mapped this unnamed fault, which we name the Martis Creek Fault, at the abrupt western edge of the Dry Lake volcanic flows. The Martis Creek Fault is inferred to extend south beneath the Martis Creek Dam and along the edge of the reservoir. Latham (1985) estimates $30 \mathrm{~m}$ of dip-slip movement on this 


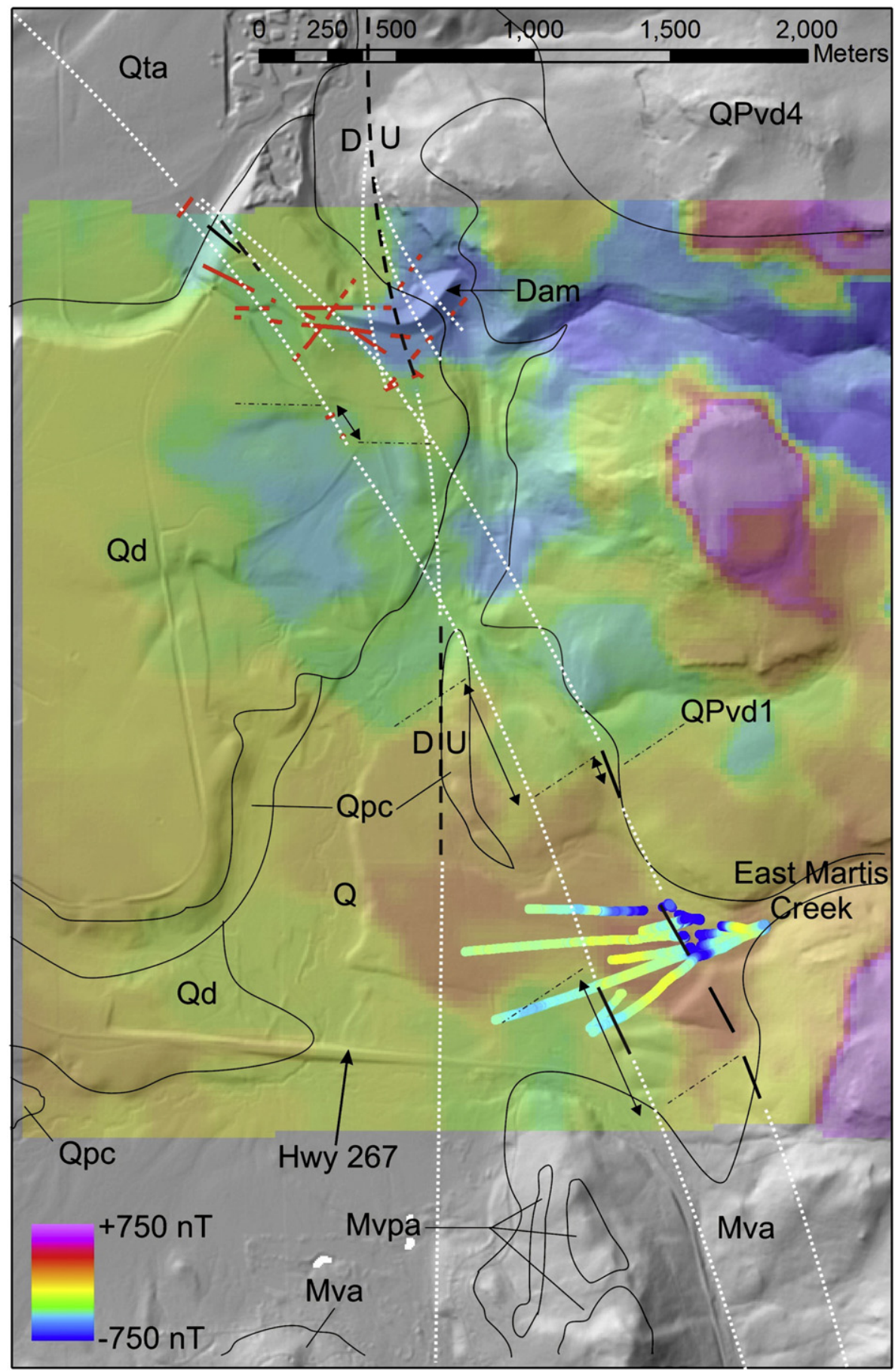

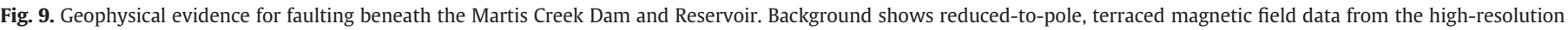

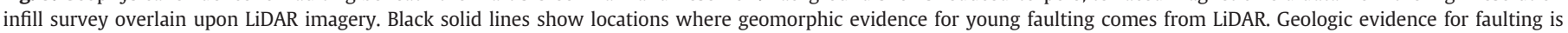

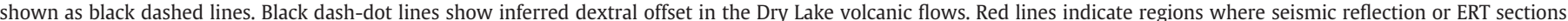

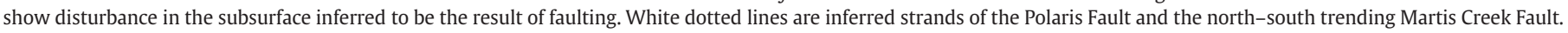

fault since 1.3 Ma (Dalrymple, 1964), based upon the offset of a basalt flow near the intersection of Martis Creek and the Truckee River. Examining the continuity of the Dry Lake volcanic flows as inferred from the airborne magnetic data, there is no indication of Quaternary strike-slip movement on this fault; hence the age of most recent activity is unknown. However, an elongated sliver of Prosser Creek alluvium just south of the Martis Creek Reservoir (Fig. 9) may have been uplifted by this fault since deposition (0.78-0.5 Ma, Latham, 1985).
Taken as a whole, at least two splays of the Polaris Fault can be traced across the spillway basin to the south end of the reservoir and across the East Martis Creek Fan. The geometry shown in Fig. 9 implies a restraining bend in the Polaris Fault near the west dam abutment, consistent with the multiple fault splays suggested by the geophysical data. Crossing the Polaris Fault is the north-south trending Martis Creek Fault, and multiple strands of this fault are inferred to pass beneath the dam itself based on geophysical evidence for faulting immediately upstream and downstream of the dam. The 
age of last activity on these faults is unknown, however multiple lines of evidence suggest they were active in the Quaternary.

\section{Conclusions}

Multi-method geophysical investigations of the Martis Creek Dam reveal a complex structural setting. The sedimentary section within the southern Truckee Basin, originally thought to be approximately $100-\mathrm{m}$ thick, is in fact part of a more extensive basin that extends to $2.5 \mathrm{~km}$ depth. Interbedded with the basin sediments are a series of Plio-Pleistocene volcanic flows, which in the survey area underlie the Martis Creek Dam and Reservoir. These volcanic flows, inferred to be part of the Dry Lake volcanic sequence, originated to the east of the reservoir, flowed several kilometers to the west from the inferred vent locations, and span at least two magnetic field reversals.

The northwest-southeast trending Polaris Fault was identified from LiDAR imagery outside of the survey area and can be continued as multiple strands beneath the dam and reservoir from ERT, seismic reflection, and ground and airborne magnetic-field measurements. Volcanic flows show offsets along the Polaris fault consistent with dextral shear, and give maximum Quaternary slip estimates of 0.2 to $0.25 \mathrm{~mm} / \mathrm{yr}$, in agreement with late Quaternary estimates of $0.4 \mathrm{~mm} / \mathrm{yr}$ based upon geomorphic evidence. The down-to-thewest, north-south trending Martis Creek Fault passes beneath the Martis Creek Dam, and structural relationships suggest it was active in the Quaternary.

The lacustrine Prosser Creek alluvium, deposited as a result of tectonic or volcanic damming of the Truckee River, forms the foundation of the Martis Creek Dam, and is overlain by a thick package of glacial outwash. Paleochannels incised within the Prosser Creek alluvium and filled with outwash were mapped using direct-current resistivity, time-domain electromagnetic, and seismic refraction surveys. The hydrogeology surrounding the Martis Creek Dam is directly controlled by the high hydraulic conductivity of the glacial outwash, the configuration of paleochannels, and the groundwater and reservoir levels. Seepage patterns observed during past reservoir test fills can be explained in terms of these factors. At the currently maintained reservoir level, the groundwater level is sufficient to form a continuous network of saturated outwash deposits that circumvents the dam, providing a pathway for seepage to the downstream side of the dam. Slight increases in the reservoir level, still well below the gross pool level, are enough to form additional pathways for seepage around the west abutment and near the dam spillway.

Disclaimer: The use of trade names is for descriptive purposes only and does not constitute endorsement by the U.S. Geological Survey.

\section{References}

Advanced Geosciences, Inc., 2008. Instruction manual for EarthImager 2D version 2.3.0-resistivity and IP inversion software. Advanced Geosciences, Inc., Austin, Tex.. 139 pp.

Al-Saigh, N.H., Mohammed, Z.S., Dahham, M.S., 1994. Detection of water leakage from dams by self-potential method. Engineering Geology 37, 115-121.

Birkeland, P.W. (1961) Pleistocene history of the Truckee area, north of Lake Tahoe, California: Stanford University, Ph.D. dissertation, 126 p., plate 1, scale 1:62,500.

Birkeland, P.W., 1963. Pleistocene volcanism and deformation of the Truckee area north of Lake Tahoe, California. Geological Society of America Bulletin 74, 1453-1464.

Birkeland, P.W., 1964. Pleistocene glaciation of the northern Sierra Nevada north of Lake Tahoe, California. Journal of Geology 72, 810-825.

Birkeland, P.W., Janda, R.J., 1971. Clay mineralogy of soils development from Quaternary deposits of the eastern Sierra Nevada, California. Geological Society of America Bulletin 82, 2495-2514.

Bolève, A., Janod, F., Revil, A., Lafon, A., Fry, J.-J., 2011. Localization and quantification of leakages in dams using time-lapse self-potential measurements associated with salt-tracer injection. Journal of Hydrology 403, 242-252.

Cedergren, H.R., 1976. Seepage study and remedial report, Martis Creek Lake, USACE Contract Report DACW05-76-C-0099. 64 pp.

Cousens, B., Prytulak, J., Henry, C., Alcazar, A., Brownrigg, T., 2008. Geology, geochronology, and geochemistry of the Miocene-Pliocene ancestral Cascades arc, northern
Sierra Nevada, California and Nevada: The roles of the upper mantle, subducting slab, and the Sierra Nevada lithosphere. Geosphere 4 (5), 829-853.

Dalrymple, G.B., 1964. Cenozoic chronology of the Sierra Nevada. University of California Publications in Geological Sciences, California. 47, 41 pp.

Egbert, G.D., 1997. Robust multiple-station magnetotelluric data processing. Geophysical Journal International 130, 475-496.

Geo-Recon Inc., 1966. Report on geophysical investigation, Martis Creek Dam Site, Truckee, California, DA-04-167-CIVENG-66-85. 7 pp.

GSI/Water, 1995. Seepage Investigation, Martis Creek Dam, Truckee, California. 59 pp.

Hammond, W.C., Blewitt, G., Kreemer, C., 2011a. Block modeling of crustal deformation of the northern Walker Lane and Basin and Range from GPS velocities. Journal of Geophysical Research 116. doi:10.1029/2010JB007817.

Hammond, W.C., Blewitt, G., Li, Z., Plag, H.-P., Kreemer, C., 2011b. Earthscope Plate Boundary Observatory reveals active uplift of the Sierra Nevada, Western United States. Geological Society of America. Abstracts with Programs 43 (5), 362.

Henry, C.D., Perkins, M.E., 2001. Sierra Nevada-Basin and Range transition near Reno, Nevada; Two stage development at $\sim 12$ and 3 Ma. Geology 29 (8), 719-722.

Hudson, F.S., 1951. Mount Lincoln-Castle Peak area, Sierra Nevada, California. Geological Society of America Bulletin 62 (8), 931-952.

Hunter, L.E., Howle, J.F., Rose, R.S., Bawden, G.W., 2011. LiDAR-assisted identification of an active fault near Truckee, California. Bulletin of the Seismological Society of America 101 (3), 1162-1181.

Latham, T.S. (1985) Stratigraphy, structure, and geochemistry of Plio-Pleistocene volcanic rocks of the western Basin and Range province, near Truckee, California: Univ. California - Davis, Ph.D. dissertation, 341 p., 1 plate, scale 1:31,000.

Lindgren, W. (1897) Description of the Truckee quadrangle (California): U.S. Geol Surv. Geologic Atlas, Folio 39.

Loke, M.H., 2010. Tutorial: 2D and 3D electrical imaging surveys. 154 pp., accessed Oct. 2010 at http://www.geoelectrical.com/downloads.php.

Louderback, G.D., 1924. Period of scarp production in the Great Basin. University of California. Publications in Geological Science 15, 1-44.

Louderback, G.D., 1906. General geologic features of the Truckee region east of the Sierra Nevada. Geological Society of America Bulletin 18, 662-669.

Melody, A.D. (2009) Active faulting and Quaternary paleohydrology of the Truckee Fault Zone North of Truckee, California. Humboldt State Univ., M.S. dissertation, 71pp.

Minsley, B.J., Burton, B.L., Ikard, S., Powers, M.H., 2011. Hydrogeophysical investigations at Hidden Dam, Raymond, California. Journal of Environmental and Engineering Geophysics 16 (4), 145-164.

Olig, S., Sawyer, T.L., Wright, D., Terra, F., 2005b. Preliminary seismic source characterization of faults near Stampede and Prosser Creek dams - Washoe Project and Boca dam - Truckee Storage Project, northern Sierra Nevada, California, Bureau of Reclamation, Denver, Colorado.

Olig S., Sawyer, T., Anderson, L., Wright, D. Wong, I., Terra, F., 2005a. Insights into Quaternary strain patterns in the northern Walker Lane from mapping and source characterization of faults near Truckee, California. Seismological Research Letters 75, 251

Osazuwa, I.B., Chinedu, A.D., 2008. Seismic refraction tomography imaging of highpermeability zones beneath an earthen dam, in Zaria area, Nigeria. Journal of Applied Geophysics 66, 44-58.

Panthulu, T.V., Krishnaiah, C., Shirke, J.M., 2001. Detection of seepage paths in earth dams using self-potential and electrical resistivity methods. Engineering Geology 59, 281-295.

Poole, D.M., Daley, A.C. (1949) A geologic section in east-central California eastward from Donner Pass, M.Sc. thesis, Univ. of Cal. - Los Angeles, 73 pp., 1 map.

Reynolds, J.M., 1997. An Introduction of Applied and Environmental Geophysics. John Wiley and Sons, New York. 796 pp.

Rodi, W., Mackie, R.L., 2001. Nonlinear conjugate gradients algorithm for 2-D magnetotelluric inversion. Geophysics 66, 174-187.

Saucedo, G.J. (2005) Geologic map of the Lake Tahoe Basin, California and Nevada California Geological Survey, Regional Geologic Map Series, 4, 1:100,000.

Schuster, G.T., Quintus-Bosz, A., 1993. Wavepath eikonal traveltime inversion: theory. Geophysics 58, 1314-1323.

Schweickert, R.A., Lahren, M.M., Smith, K.D., Howle, J.F., Ichinose, G., 2004. Transtensional deformation in the Lake Tahoe region, California and Nevada, USA. Tectonophysics 392, 303-323.

Sjödahl, P., Dahlin, T., Johansson, S., Loke, M.H., 2008. Resistivity monitoring for leakage and internal erosion detection at Hällby embankment dam. Journal of Applied Geophysics $65,155-164$.

Song, S.-H., Song, Y., Kwon, B.-D., 2005. Application of hydrogeological and geophysical methods to delineate leakage pathways in an earth fill dam. Exploration Geophysics 58, 92-96.

Sylvester, A.G., Wise, W.S., Hastings, J.T., Moyer, L.A., 2007. New digital geologic map of the Tahoe-Donner Pass region, Northern Sierra Nevada, California. Geological Society of America. Abstracts 39 (5), 37

Titov, K., Lokhmanov, V., Potapov, A., 2000. Monitoring of water seepage from a reservoir using resistivity and self polarization methods: Case history of the Petergoph fountain water supply system. First Break 18, 431-435.

USACE, 1966. Site Geology Report, Design Memorandum No. 8, US Army Corps of Engineers. 46 pp.

USACE, 1972. Foundation report. US Army Corp of Engineers, Martis Creek Lake. 141 pp. USACE, 1996. 1995 Test Fill Report. U.S. Army Corps of Engineers, Martis Creek Dam. 132 pp. Thompson, G.A., White, D.E., 1964. Regional geology of the Steamboat Springs area, Washoe County, Nevada, USGS Prof. Paper 458-A. 52 pp.

Yount, J., LaPointe, D.D., 1997. Glaciation, faulting, and volcanism in the southern Lake Tahoe basin. Natl. Assoc. of Geoscience Teachers, 1997 Fall Field Conference, pp. 1-22.

Zhang, J., Toksoz, M.N., 1998. Nonlinear refraction traveltime tomography. Geophysics 63, 1726-1737. 